\title{
RESULTS OF TREATMENT OF ACUTE LUMBAR DISC HERNIATION WITH TRANSFORAMINAL NERVE ROOT BLOCK
}

\author{
RESULTADOS DO TRATAMENTO DA HÉRNIA DISCAL LOMBAR AGUDA COM BLOQUEIO \\ ANESTÉSICO TRANSFORAMINAL
}

\author{
RESULTADOS DEL TRATAMIENTO DE LA HERNIA DISCAL LUMBAR CON BLOQUEO \\ ANESTESICO TRANSFORAMINAL
}

Emiliano Neves Vialle ${ }^{1}$, Wellington Keity Ueda ${ }^{1}$, Luiz Roberto Gomes Vialle ${ }^{1,2}$

1. Pontifícia Universidade Católica do Paraná, Hospital Universitário do Cajuru, Spine Surgery Group, Curitiba, PR, Brazil.

2. Pontifícia Universidade Católica do Paraná, Escola de Medicina, Orthopedics and Traumatology, Curitiba, Paraná, Brazil.

\begin{abstract}
Objective: To determine the efficacy of anesthetic transforaminal nerve root block in patients with sciatica secondary to lumbar disc herniation through a prospective observational study. Methods: The study included 176 patients from a private clinic undergoing transforaminal injection performed by a single spinal surgeon. The patients were assessed after two weeks, three months and six months regarding to the improvement of the pain radiating to the lower limbs. In case of persistent symptoms, patients could choose to perform a new nerve root block and maintenance of physical therapy or be submitted to conventional microdiscectomy. Results: By the end of six-month follow-up of the 176 patients, 116 had a favorable outcome (95 after one block and 21 after two blocks), and only 43 required surgery. Conclusion: The results of our study suggest a positive effect of transforaminal block for the treatment of sciatica in patients with lumbar disc herniation.
\end{abstract}

Keywords: Sciatica; Radiculopathy; Intervertebral disc displacement; Injections, epidural; Steroids.

\section{RESUMO}

Objetivo: Determinar a eficácia do bloqueio anestésico transforaminal nos pacientes com ciática secundária à hérnia de disco lombar, por meio de um estudo prospectivo observacional. Métodos: Foram incluídos no estudo 176 pacientes de uma clínica privada submetidos à injeção transforaminal executada por um único cirurgião de coluna. Os pacientes foram reavaliados após duas semanas, três meses e seis meses quanto à melhora da dor irradiada para os membros inferiores. Na persistência dos sintomas, os pacientes poderiam optar por realizar um novo bloqueio e manutenção da fisioterapia ou serem submetidos à microdiscectomia convencional. Resultados: No final do seguimento de seis meses dos 176 pacientes, 116 apresentaram evolução satisfatória (95 após um bloqueio e 21 após dois bloqueios) e apenas 43 necessitaram da cirurgia. Conclusão: Os resultados do nosso estudo sugerem um efeito positivo do bloqueio transforaminal para o tratamento da ciatalgia nos pacientes com hérnia de disco lombar.

Descritores: Ciática; Radiculopatia; Deslocamento do disco intervertebral; Injeções epidurais; Esteroides.

\section{RESUMEN}

Objetivo: Determinar la eficacia del bloqueo anestésico transforaminal en pacientes con dolor radicular secundario a hernia de disco lumbar, a través de un estudio prospectivo observacional. Métodos: El estudio fue compuesto por 176 pacientes de una clínica privada sometidos al bloqueo anestésico transforaminal realizado por un único cirujano de la columna. Los pacientes fueron re-evaluados al cabo de dos semanas, tres meses y seis meses con respecto a la mejora del dolor que se irradia a las extremidades inferiores. En caso de persistencia de los síntomas los pacientes podrian optar por realizar un nuevo bloqueo anestésico y mantenimiento de fisioterapia o someterse a una microdiscectomía convencional. Resultados: Al final del seguimiento de seis meses de los 176 pacientes, 116 tuvieron resultado favorable (95 luego de sólo un bloqueo y 21 después de dos bloqueos) y en solamente 43 pacientes la cirugía fue necesaria. Conclusión: Los resultados de nuestro estudio sugieren un efecto positivo del bloqueo anestésico transforaminal para el tratamiento de la ciática en los pacientes con hernia de disco lumbar.

Descriptores: Ciática; Radiculopatía; Desplazamiento del disco intervertebral; Inyecciones epidurales; Esteroides.

\section{INTRODUCTION}

Low back pain and lumbosciatica are among the most common reasons for medical consultations in Western societies, and lumbar disc herniation $(\mathrm{LDH})$ is the principal ca usal factor (in about $50 \%$ of cases). ${ }^{1}$ Intervertebral disc herniation in the direction of the nerve root results in an self-limiting inflammatory response in the surrounding area which, in association with mechanical compression, generates radicular pain. ${ }^{2,3}$ The significant social impact of costs arising from time off work, medications, physical therapy treatments, and surgeries has been a factor of considerable importance from an economic point of view. According to several estimates, the total annual cost in the United States is close to one hundred million dollars. ${ }^{4}$ The cost for patients treated conservatively was $\$ 50,000$ per case over five years in the United States, with a prevalence of male patients of working age (25-64 years of age). ${ }^{3}$ 
Although sciatica from disc herniation is a benign condition, having a favorable and auto-limiting natural history, it can be highly symptomatic, causing pain with functional limitations due to the inflammatory process of the nerve root. For this reason, pain control is an important part of conservative LDH treatment until spontaneous resolution. ${ }^{5}$

Conservative forms of treatment include the use of analgesics and anti-inflammatory agents, physical therapy, manual therapies, and epidural blocks. Epidural steroid injections have proven to be a low-risk alternative in some patients for whom other treatments have not been effective. ${ }^{6,7}$

There are three forms of epidural steroid injections: caudal, interlaminar, and transforaminal. The transforaminal method is preferred by the authors because of the smaller amount of medication necessary and the proximity of the infiltration location to the nerve root. ${ }^{8}$ Additionally, diffusion of the drug in the anterior part of the dural sac is more effective ${ }^{9}$ due to the relationship with the nociceptive fibers in the anterior region of the root and the dorsal ganglion. ${ }^{5}$

Transforaminal epidural injection can be an effective tool in the treatment of sciatica in the short-term acute phase, with the potential to reduce costs for society by reducing time away off work and lost productivity.

The objective of this study was to report the authors' experience with anesthetic transforaminal block in patients with lumbar disc herniation, with an emphasis on the clinical improvement of patients and on reducing the rate of post-procedure surgeries.

\section{MATERIAL AND METHODS}

This prospective observational study was conducted between January 2011 and December 2014. All the patients included in the study were diagnosed with acute lumbar disc herniation revealed in magnetic resonance imaging exams, and had experienced up to eight weeks of sciatic pain. All the individuals signed the informed consent form for the use of their data for scientific purposes. The data was collected as part of a project approved by the Institutional Review Board, under number 21350513.1.0000.0020.

The study group consisted of 176 patients, out of a total of 280 patients diagnosed with lumbar disc herniation, 68 of whom were women and 108 of whom were men. Their ages ranged from 0 to 87 years, averaging 49.66 years of age. The most common location of the hernias was in the L4-L5 space, followed by the L5-S1 space. (Table 1)

The main inclusion criterion was radicular pain (below the knee for low lumbar hernias and in the anterior region of the thigh for upper lumbar hernias) and evidence of nerve irritation determined by signs of tensioning of the nerve root (positive straight leg raise test between $30^{\circ}$ and $70^{\circ}$ or positive Nachlas test) or the presence of neurological deficit (reduced sensitivity in a dermatomal distribution or weakness in a myotomal distribution). The other study inclusion criteria are displayed in Table 2.

All injections were performed by a single surgeon specializing in spine surgery. During the follow-up period, the patients were monitored by the same physical therapy and rehabilitation team.

To perform the procedure, the individuals were positioned in ventral decubitus and the injection location was marked with the aid of a fluoroscope. After proper disinfection, the skin and subcutaneous tissue were infiltrated with $2 \mathrm{ml}$ of $2 \%$ lidocaine. A 22G $(0.70 \mathrm{~mm}) \mathrm{X}$ 3.1/2" rachianesthesia needle was introduced up to the intervertebral foramen, identified with the assistance of the radioscope, and then a non-ionic contrast agent was injected under continuous radioscope

Table 1. Distribution of herniated discs by level.

\begin{tabular}{c|c|c}
\hline Level & $\mathbf{n}$ & $\%$ \\
\hline L1-L2 & 2 & 1.13 \\
\hline L2-L3 & 8 & 4.54 \\
\hline L3-L4 & 28 & 15.90 \\
\hline L4-L5 & 74 & 42.4 \\
\hline L5-S1 & 64 & 36.36 \\
\hline
\end{tabular}

visualization to monitor the distribution of the contrast agent in the epidural space and to avoid an intravascular injection. (Figure 1) Once the correct placement of the needle was confirmed, an infiltration of $1 \mathrm{ml}$ of $2 \%$ lidocaine and $4 \mathrm{mg}$ of betamethasone sodium phosphate filtration was applied. In case of significant radicular pain during application, the needle was repositioned and a new application of contrast injected to confirm an extravascular and extraneural position.

All the patients were instructed to continue conservative treatment with active physical therapy and exercises at home, in addition to using simple analgesics, as needed. They were reevaluated after two weeks, three months, and six months, using the same assessment method consisting of an analysis of sciatic pain on a scale from zero to ten, subsequently represented as a percentage of pain relief.

At the two-week evaluation, the patients were divided into three groups. The first group (G1) was comprised of those who had complete relief (more than 90\%), the second group (G2) of those with partial improvement of their symptoms (from $50 \%$ b to $90 \%$ ), and finally, the third group (G3) of those who reported no significant improvement (less than 50\%). (Figure 2)

Patients who were symptomatic in subsequent evaluations became candidates for another block.

Table 2. Study inclusion and exclusion criteria, and contraindications.

\begin{tabular}{c|c|c}
\hline Inclusion & Exclusion & $\begin{array}{c}\text { Contraindications for a } \\
\text { block }\end{array}$ \\
\hline $\begin{array}{c}\text { Unilateral sciatica as } \\
\text { main symptom }\end{array}$ & Bilateral sciatica & Cauda equina syndrome \\
\hline $\begin{array}{c}\text { Disc herniation at one } \\
\text { level (MR) }\end{array}$ & $\begin{array}{c}\text { Disc herniation at more } \\
\text { than one level (MR) }\end{array}$ & Lumbar canal stenosis (MR) \\
\hline $\begin{array}{c}\text { Up to } 8 \text { weeks of } \\
\text { evolution }\end{array}$ & $\begin{array}{c}\text { More than 8 weeks of } \\
\text { evolution }\end{array}$ & Drug allergies \\
\hline $\begin{array}{c}\text { Failure of conservative } \\
\text { treatment }\end{array}$ & $\begin{array}{c}\text { Absence of } \\
\text { conservative treatment }\end{array}$ & Diabetes \\
\hline $\begin{array}{c}\text { Minimum 6-month } \\
\text { follow-up }\end{array}$ & $\begin{array}{c}\text { Less than 6-month } \\
\text { follow-up }\end{array}$ & Glaucoma \\
\hline $\mathrm{n}=176$ & Lumbar spine surgery & $\mathrm{n}=22$ \\
\hline
\end{tabular}

$\mathrm{MR}=$ magnetic resonance; $\mathrm{n}=$ number of patients.

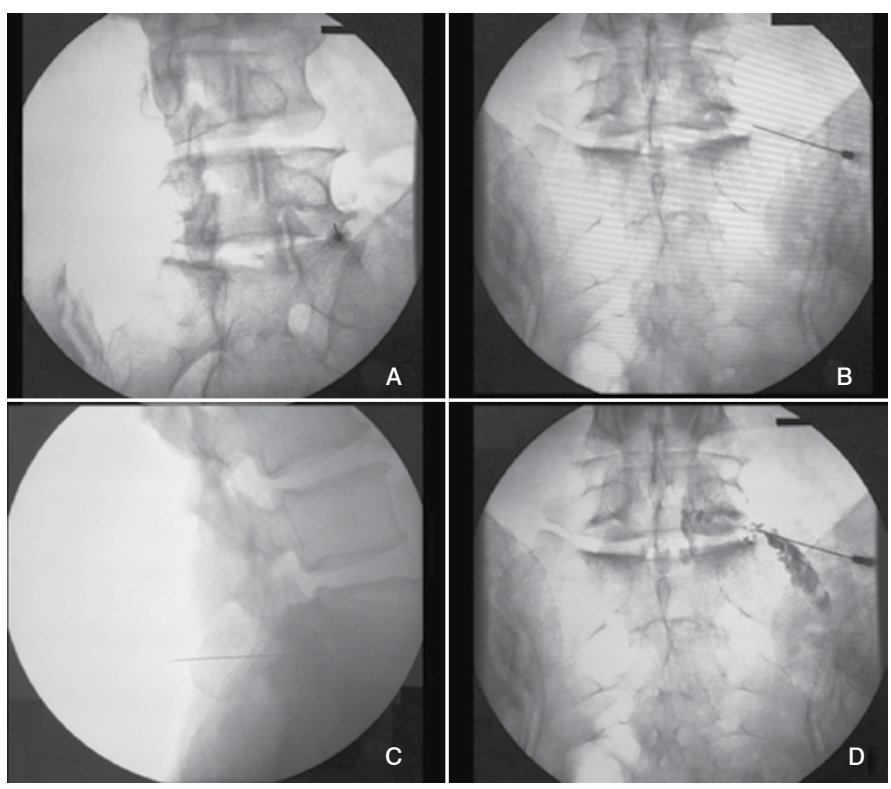

Figure 1. A) Location of the point of injection for the $L 5$ root block in the oblique plane. B) Positioning of the needle in the neural foramen in the AP incidence. C) Positioning of the needle in the neural foramen in the profile incidence. D) After injection of the non-ionic contrast agent, image of the path of the L5 root confirming the correct needle positioning. 
Those who elected to undergo a new block were once again referred for physical therapy following the procedure and reevaluated according to the same schedule.

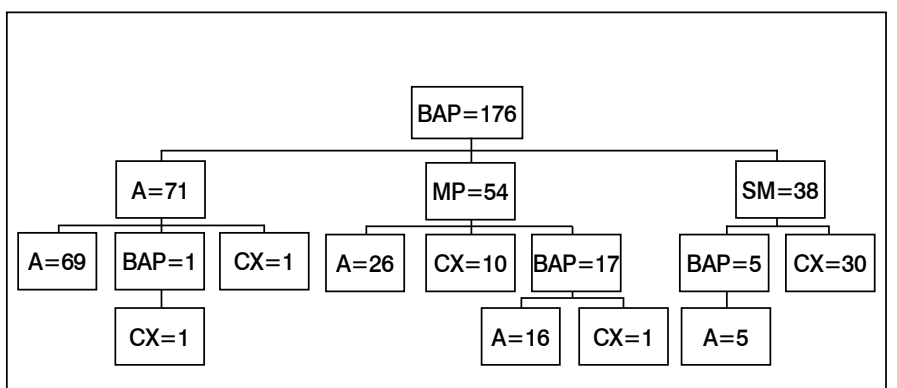

BAP: Anesthetic foraminal block, A: Asymptomatic, MP: Partial improvement, SM: No improvement, CX: Surgery

Figure 2. Chart showing the stratification of the disc herniation treatment results. In the partial improvement and no improvement groups, 4 patients opted not to undergo either a new block or surgery and were referred for clinical pain management.

\section{RESULTS}

The primary endpoint of the study was pain relief. The patients were divided into three groups during the evaluation at two weeks following the procedure. Group 1 included patients who had complete pain relief $(n=71)$, and of this group, only one patient was referred for surgery and another for a second transforaminal injection.

In Group 2, made up of patients with between $50 \%$ and $90 \%$ relief $(n=54), 10$ patients underwent surgical treatment after the first block and 17 patients opted for a new block. Only one patient required surgery following the second procedure. One patient in this group, who did not experience significant improvement with the first block, opted to follow a course of strictly drug treatment.

In Group 3, consisting of patients who reported less than 50\% improvement $(n=38), 30$ patients underwent surgery and five decided to undergo a new block, this time with a favorable outcome. Three patients were referred for clinical pain treatment.

No patient experienced any complication resulting from the block either during or following the procedure. At the end of the study, of the 176 patients, 13 did not complete the minimum six-month followup and were subsequently excluded from the statistical analysis. Of the 163 remaining individuals, 116 (71.63\%) made good progress, achieving a favorable outcome with conservative treatment.

Another important aspect of the data is that of the $23(14.11 \%)$ patients who underwent a second block, 21 showed good progress and did not require any additional procedure during the rest of the study. This demonstrates that the technique is highly effective in cases of new indications for individuals with persistent symptoms.

Microdiscectomy was performed in 43 (26.38\%) patients, and four $(2 \%)$ of the individuals without satisfactory block results opted to follow a regime of clinical treatment for pain, only.

\section{DISCUSSION}

Since Mixter and Barr first described the correlation between sciatica and disc herniation ${ }^{10}$ in 1934 , both the conservative and surgical modes of treatment for this pathology have evolved significantly. This study reports results from the use of transforaminal block as a component of conservative treatment of sciatic pain secondary to LDH. The objective of ATB (anesthetic transforaminal block) in these patients was to reduce the rate of surgery by allowing the patients to tolerate the symptoms for a longer period of time. ${ }^{11}$

Most patients with symptomatic LDH do not undergo surgical treatment because the course and prognosis are generally favorable, with similar long-term outcomes regardless of the treatment received. ${ }^{12}$

The natural history of sciatica is of short duration, followed by a phase with residual symptoms. Most patients' symptoms improve within a few weeks, with the most severely extruded discs experiencing the greatest rate of reduction in size. ${ }^{13}$ Clinical improvement tends to occur earlier than morphological changes to the disc. ${ }^{14}$

The patients included in this study were selected from among those with persistent symptoms despite conservative treatment and who already presented the criteria for a surgical indication. After the introduction of ATB as a routine treatment for symptomatic $\mathrm{LDH}$, the rate of herniated disc surgeries dropped considerably as compared to the prior experience of other authors. ${ }^{11}$

There are three infiltration modalities that allow the application of medication into the epidural space. The interlaminar approach delivers the medication near the assumed location of the pathology. The caudal epidural approach is considered to be the easiest and safest, with minimal risk of inadvertent puncture, but it requires a larger volume of medication because of the lack of specificity for the location of the pathology. Finally, the transforaminal approach is considered to be target-specific and requires a smaller volume of medication to act on the source of the pain. ${ }^{15}$

Regarding the choice of an infiltration approach, Manchikanti et al. ${ }^{15}$ in their recent systematic review found that caudal epidural, interlaminar, and transforaminal injections guided by fluoroscope are all effective in managing sciatic pain, in terms of both pain relief and functional improvement.

The use of contrast agents in transforaminal injection guided by radioscopy is justified because it improves the accuracy of locating the nerve root and thus, an injection of a smaller volume of medication, ${ }^{16}$ besides reducing the risk of intravascular drug administration.

The use of corticosteroids in our routine was justified by the increase in the absorption rate of extruded hernias after two months, ${ }^{17}$ despite their potential complications, such as an increase in blood glucose levels in diabetic patients. ${ }^{18}$

Atlas et al. ${ }^{19}$ evaluated the outcomes of patients who underwent surgical and non-surgical treatment for lumbar disc herniation and found similar improvement of both the predominant symptoms and work status regardless of the treatment received, although the patients who underwent surgery had a higher level of satisfaction.

Riew et al. ${ }^{20}$ found that $81 \%$ of the patients submitted to ATB did not require any surgical intervention after 5 years of follow-up, results that can be compared to those achieved in our study, where $71.16 \%$ evolved well with conservative treatment. Another important factor to consider is the application of ATB in determining patient prognosis. The authors recommend continuation of conservative treatment for patients who experience significant relief, and in cases with an unsatisfactory response to ATB, particularly after the second procedure, the surgical option is most often recommended.

Despite the relatively short follow-up period, the final treatment endpoint was defined for all patients in the study, with the exception of those who abandoned the protocol. Another limitation of this study was that the hernias were not classified by volume and location, due to the diversity of MRI patterns presented.

\section{CONCLUSION}

The results of our study suggest a positive effect from foraminal block in the treatment of sciatic pain triggered by lumbar disc herniation.

After six months of evolution, the patients who experienced significant relief from the symptoms with the block $(71.16 \%)$ were able to complete routine conservative physical therapy and avoid surgery.

Patients with partial or insufficient relief opted for surgery in $26.38 \%$ of the cases.

All the authors declare that there are no potential conflicts of interest regarding this article. 
CONTRIBUTIONS OF THE AUTHORS: Each author made significant individual contributions to the development of the manuscript. ENV conducted the surgical procedures, performed data collection, and participated in the writing and revision of the article. LRGV and WKU participated in the writing and revision of the article. All the authors contributed to the intellectual concept of the study.

\section{REFERENCES}

1. Manchikanti L, Singh V, Falco FJ, Cash KA, Pampati V. Evaluation of the effectiveness of lumbar interlaminar epidural injections in managing chronic pain of lumbar disc herniation or radiculitis: a randomized, double-blind, controlled trial. Pain Physician. 2010;13(4):343-55.

2. Arden NK, Price C, Reading I, Stubbing J, Hazelgrove J, Dunne C, et al. A multicentre randomized controlled trial o epidural corticosteroid injections for sciatica: the WEST study. Rheumatology (Oxford). 2005;44(11):1399-406.

3. Spijker-Huiges A, Vermeulen K, Winters JC, van Wijhe M, van der Meer K. Costs and cost-effectiveness of epidural steroids for acute lumbosacral radicular yndrome in general practice: an economic evaluation alongside a pragmatic randomized control trial. Spine (Phila Pa 1976). 2014;39(24):2007-12.

4. Crow WT, Willis DR. Estimating cost of care for patients with acute low back pain: a retrospective review of patient records. J Am Osteopath Assoc. 2009;109(4):229-33.

5. Vialle $E$, Vialle LR, Contreras W, Jacob Junior C. Anatomical study on the relationship between the dorsal root ganglion and the intervertebral disc in the lumbar spine. Rev Bras Ortop. 2015;50(4):450-4.

6. Buttermann GR. Treatment of lumbar disc herniation: epidural steroid injection compared with discectomy. A prospective, randomized study. J Bone Joint Surg Am. 2004;86(4):670-9.

7. Johnson BA, Schellhas KP, Pollei SR. Epidurography and therapeutic epidural injections: technical considerations and experience with 5334 cases. AJNR Am J Neuroradiol. 1999;20(4):697-705.

8. Atcheson SG, Dymeck T. Rapid resolution of chronic sciatica with intravenous infliximab after failed epidural steroid injections. Spine (Phila Pa 1976). 2004;29(12):E248-50.

9. Jeong HS, Lee JW, Kim SH, Myung JS, Kim JH, Kang HS. Effectiveness of transforaminal epidural steroid injection by using a preganglionic approach: a prospective randomized controlled study. Radiology. 2007:245(2):584-90.

10. Mixter WJ, Barr JS. Rupture of the intervertebral disc with involvement of the spinal cord. N Engl J Med. 1934;211:210-4.
11. Vialle LR, Vialle EN, Suárez Henao JE, Giraldo G. Lumbar disc herniation. Rev Bras Ortop. 2015;45(1):17-22.

12. Jacobs WC, van Tulder M, Arts M, Rubinstein SM, van Middelkoop M, Ostelo R, et al. Surgery versus conservative management of sciatica due to a lumbar herniated disc: a systematic review. Eur Spine J. 2011;20(4):513-22.

13. Bozzao A, Gallucci M, Masciocchi C, Aprile I, Barile A, Passariello R. Lumbar disk herniation: MR imaging assessment of natural history in patients treated without surgery. Radiology. 1992;185(1):135-41.

14. Komori H, Shinomiya K, Nakai O, Yamaura I, Takeda S, Furuya K. The natural history of herniated nucleus pulposus with radiculopathy. Spine (Phila Pa 1976). 1996;21(2):225-9.

15. Manchikanti L, Benyamin RM, Falco FJ, Kaye AD, Hirsch JA. Do epidural injections provide short- and long-term relief for lumbar disc herniation? A systematic review. Clin Orthop Relat Res. 2015;473(6):1940-56.

16. Thomas E, Cyteval C, Abiad L, Picot MC, Taourel P, Blotman F. Efficacy of transforaminal versus interspinous corticosteroid injectionin discal radiculalgia-a prospective, randomised, double-blind study. Clin Rheumatol. 2003;22(4-5):299-304.

17. Autio RA, Karppinen J, Kurunlahti M, Haapea M, Vanharanta $H$, Tervonen O. Effect of periradicular methylprednisolone on spontaneous resorption of intervertebral disc herniations. Spine (Phila Pa 1976). 2004;29(15):1601-7.

18. Even JL, Crosby CG, Song Y, McGirt MJ, Devin CJ. Effects of epidural steroid injections on blood glucose levels in patients with diabetes mellitus. Spine (Phila Pa 1976). 2012;37(1):E46-50.

19. Atlas SJ, Keller RB, Chang Y, Deyo RA, Singer DE. Surgical and nonsurgical management of sciatica secondary to a lumbar disc herniation: five-year outcomes from the Maine Lumbar Spine Study. Spine (Phila Pa 1976). 2001;26(10):1179-87.

20. Riew KD, Park JB, Cho YS, Gilula L, Patel A, Lenke LG, et al. Nerve root blocks in the treatment of lumbar radicular pain. A minimum five-year follow-up. J Bone Joint Surg Am. 2006;88(8):1722-5. 